\title{
Active Immunization against Transforming Growth Factor- beta1 Prevents Hepatic Fibrosis in a Rat Model of Liver Disease
}

\begin{tabular}{|c|c|}
\hline Journal: & Canadian Journal of Physiology and Pharmacology \\
\hline Manuscript ID & cjpp-2016-0669.R1 \\
\hline Manuscript Type: & Article \\
\hline Date Submitted by the Author: & 16-Dec-2016 \\
\hline Complete List of Authors: & $\begin{array}{l}\text { Ji, Hong; University of Manitoba, Department of Internal Medicine, College } \\
\text { of Medicine, Rady Faculty of Health Sciences } \\
\text { Minuk, Gerald; University of Manitoba, Internal Medicine, College of } \\
\text { Medicine, Rady Faculty of Health Sciences } \\
\text { Peng, Zhikang; University of Manitoba } \\
\text { Chen, Yongping; Wenzhou Medical University, Department of Infection } \\
\text { Disease, the First Affiliated Hospital } \\
\text { Pan, Chenwei; Wenzhou Medical University, Department of Infection } \\
\text { Disease, the Second Affiliated Hospital } \\
\text { Gong, Yuewen; University of Manitoba, College of Pharmacy }\end{array}$ \\
\hline Keyword: & $\begin{array}{l}\text { transforming growth factor-beta } 1 \text {, hepatitis B virus core protein, } \\
\text { recombinant protein, liver fibrosis }\end{array}$ \\
\hline
\end{tabular}




\section{Active Immunization against Transforming Growth Factor-beta1 Prevents Hepatic Fibrosis in a Rat Model of Liver Disease}

Hong Ji ${ }^{1,2}$, Gerald Y. Minuk ${ }^{2}$, Zhikang Peng ${ }^{3}$, Yongping Chen ${ }^{4}$, Chenwei Pan ${ }^{4}$, and Yuewen Gong ${ }^{1,2}$.

${ }^{1}$ College of Pharmacy, Rady Faculty of Health Sciences, University of Manitoba ${ }^{2}$ Section of Hepatology, Department of Internal Medicine, College of Medicine, Rady Faculty of Health Sciences, University of Manitoba, ${ }^{3}$ Department of Pediatrics \& Child Health, Faculty of Medicine, University of Manitoba, Winnipeg, Manitoba, Canada, ${ }^{4}$ The First Affiliated Hospital, Wenzhou Medical College, Wenzhou, Zhejiang Province, China,

Running Title: TGF- $\beta$ vaccination and fibrosis

Word Count: 5359, Pages 22, Figures 5, Tables 2

Acknowledgements: The research was supported by a grant (MOP-62923) from Canadian Institute of Health Research to Dr. Yuewen Gong.

Corresponding Author: $\quad$ Dr. Yuewen Gong Faculty of Pharmacy University of Manitoba 315 Apotex Centre $750 \mathrm{McDermot}$ Avenue Winnipeg, MB, Canada, R3E 0T5

Yuewen.gong@umanitoba.ca 


\section{ABSTRACT}

Transforming growth factor-beta1 (TGF- $\beta 1$ ) plays an important role in hepatic fibrogenesis. To document the effects of active immunization against TGF- $\beta 1$ on hepatic fibrosis in an animal model of chronic liver disease. BALB/c mice were immunized against three different peptides of TGF- $\beta 1$ ligated into hepatitis B virus core protein $(\mathrm{HBVc})$. Titers of TGF- $\beta 1$ antibodies were documented by enzyme linked immunoassays and antibody activity by cell membrane receptor binding and proliferation assays. The most immunogenic recombinant $\mathrm{HBVc}+\mathrm{TGF}-\beta 1$ peptide $(\mathrm{HBV}+\mathrm{C})$ then served as a vaccine in Sprague-Dawley rats with dimethylnitrosamine-induced chronic liver disease. Hepatic fibrosis was documented by serum hyaluronic acid levels, liver histology and real time polymerase chain reaction for hepatic collagen $1(\alpha 1)$ and alpha-smooth muscle actin mRNA expression. Relative to control rats vaccinated with $\mathrm{HBVc}$ alone, recombinant $\mathrm{HBVc}+\mathrm{C}$ vaccinated animals had significantly lower serum hyaluronic acid levels, less histologic evidence of hepatic fibrosis and reduced expression of collagen type 1( $\alpha 1)$ and alpha-smooth muscle actin mRNA in the liver. The results of this proof-of-concept study suggest that active immunization against TGF- $\beta 1$ is a worthwhile strategy to pursue in efforts to prevent hepatic fibrosis associated with chronic liver disease.

Key Words: transforming growth factor-beta1, hepatitis B virus core protein, recombinant protein, liver fibrosis. 


\section{INTRODUCTION}

Hepatic fibrosis is a common consequence of chronic, necroinflammatory disease of the liver. Of the various cytokines implicated in the pathogenesis of hepatic fibrosis, transforming growth factor-beta1 (TGF- $\beta 1$ ) is thought to be primarily involved and certainly, has been the most extensively studied (Alcolado et al. 1997; Biernacka et al. 2011). Some of the more compelling findings include; 1 ) TGF- $\beta 1$ transgenic mice develop significant hepatic fibrosis whereas normal mice do not (Clouthier et al. 1997; Sanderson et al. 1995), 2) dominant-negative TGF-beta Type II receptors protect against the fibrosis induced by hepatotoxicity (Qi et al. 1999), 3) soluble Type II receptors inhibit hepatic stem cell (HSC) activation (George et al. 1999) and attenuate hepatic fibrosis induced by carbon tetrachloride (CCl4) (Yata et al. 2002), and 4) daily injections of a peptide - Leu-Ser-Lys-Leu (LSKL) - which represents the specific amino acid sequences at the amino terminus of latency-associated peptide, inhibits TGF- $\beta 1$ activation and prevents hepatic fibrosis in vivo (Kondou et al. 2003).

TGF- $\beta 1$ acts by binding to TGF- $\beta$ type II receptors present on the surface of HSCs resulting in the aggregation and formation of Type I-II receptor complexes and phosphorylation of the Type I receptor at GS domains (Derynck 1998). Activated Type I receptors then phosphorylate Smad 2/3 molecules which associate with Smad 4 to initiate the transcription of genes responsible for HSC proliferation and transformation into myofibroblasts and ultimately, collagen formation (Dooley et al. 2001).

From a clinical perspective, efforts have focused on interfering with TGF- $\beta 1$ mediated signaling. These efforts have included the use of angiotensin converting enzyme (ACE) inhibitors, ACE receptor blockers, beta adrenergic blockers and more direct approaches such as infusions of soluble TGF- $\beta$ receptors and passively administering antibodies to TGF- $\beta 1$ (Choi et al. 2007; Karimian et al. 2008; Kondou et al. 2003; Strack et al. 2011; Tox and Steffen 2006; Wei et al. 2004). To our knowledge, there 
have been no previous attempts to determine whether active immunization against TGF- $\beta 1$ peptides prevents or attenuates hepatic fibrogenesis in the setting of chronic liver disease.

\section{MATERIALS AND METHODS}

Construction of vector and immunization of mice: A vector of pThioHisA (Invitrogen, CA) with hepatitis B virus core protein cDNA (552 bp), was kindly provided by Dr. Zhikang Peng at the University of Manitoba. The three antigenic peptide domains of TGF- $\beta 1$ were identified by using online software of Antigenic peptide prediction (http://immunax.dfci.harvard.edu/Tools/antigenic.html) according to human TGF- $\beta 1$ nucleotide sequences (NP000651). Three pairs of oligonucleotides with Kpn1 sites at both ends were synthesized by Invitrogen (Table 1). Recombinant plasmids (pThioHisAHBVc+A, pThioHisA-HBVc+B, and pThioHisA-HBVc+C) were successfully constructed by standard methods. After purification of these recombinant proteins by standard methods, they were employed to immunize mice.

Immunization of mice: All animals received care in compliance with the Institution's guidelines (Animal Protocol No. 02-007) and in accordance with the Canadian Council on Animal Care. Thirty female BALB/c mice (body weight approximately 20g) were purchased and maintained in the Central Animal Facility at the University of Manitoba. Mice were separated into five groups ( $n=6 /$ group): 1) Complete Freund's adjuvant only, 2) adjuvant plus HBVc, 3) adjuvant plus HBVc+A, 4) adjuvant plus $\mathrm{HBVc}+\mathrm{B}$, and 5) adjuvant plus recombinant $\mathrm{HBVc}+\mathrm{C}$. Immunization of mice was performed as per our

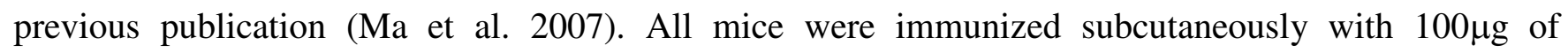
recombinant protein. Two weeks after the first injection, a $50 \mu \mathrm{g}$ boost was administered. Mice were sacrificed after an additional two weeks by exsanguination. Serum was collected and stored at $-80^{\circ} \mathrm{C}$ until used for subsequent determinations. 
Enzyme-linked immunosorbent assay (ELISA): An indirect ELISA was employed to screen or identify the antigenic activity of recombinant HBVc-TGF- $\beta 1$ fragments $(\mathrm{HBVc}+\mathrm{A}, \mathrm{HBVc}+\mathrm{B}, \mathrm{HBV}+\mathrm{C}$ or TGF$\beta 1$ ) in immunized mice as described previously (Ma et al. 2007). Polystyrene 96-well plates were coated with $100 \mu$ l recombinant proteins $(4 \mu \mathrm{g} / \mathrm{ml})$ or $100 \mu 1$ recombinant TGF- $\beta 1(1 \mathrm{ng} / \mathrm{ml}$ from R\&D System) in $0.05 \mathrm{M}$ carbonate buffer ( $\mathrm{pH} 9.6)$ and incubated overnight at $4^{0} \mathrm{C}$. After blocking and washing, different dilutions of mouse sera were added and incubated at $4^{0} \mathrm{C}$ overnight. Wells were washed and $0.1 \mathrm{ml}$ of enzyme-conjugated goat anti-mouse IgG (Sigma, MO, USA) (1:1000 diluted in PBS-T supplemented with $0.2 \% \mathrm{BSA}$ ) was added and incubated for 1 hour at $37^{\circ} \mathrm{C}$. Color reaction was developed by adding $0.1 \mathrm{ml}$ of enzyme substrate $(1 \mathrm{mg} / \mathrm{ml}$ P-nitrophenylphosphate in $0.2 \mathrm{M}$ Tris buffer, $\mathrm{pH} 9.8$, Sigma Fast pnitrophenylphosphate tablets) and incubating at room temperature for 1 hour. Absorbance at 405nm was read using a THERMOmax microplate reader (Molecular Devices, CA). Negative controls included coated wells with no mouse serum or no goat anti-mouse IgG in PBS-T with $0.2 \%$ BSA. The positive control was a polyclonal antibody against TGF- $\beta 1$ from R\&D System (Minneapolis, MN).

Cellular membrane receptor binding assay: The Mink lung epithelial cell line (CCL64) was selected for cellular membrane receptor binding assays because of the high density of TGF- $\beta 1$ receptors presented on its cell membrane (Kramer et al. 1991). These cells were purchased from ATCC and cultured in DMEM with 5\% FBS. Mouse IgG was isolated from mouse serum by incubating $1 \mathrm{ml}$ of mouse serum with $2 \mathrm{ml}$ protein $\mathrm{A} / \mathrm{G}$ solution (Sigma, MO, USA) at $4^{0} \mathrm{C}$ for 1 hour and washed three times with PBS (pH 7.4). IgG was then eluted from protein A/G by incubating with $0.2 \mathrm{M}$ Glycine $\mathrm{pH}$ 3.0 twice and neutralized with $1 \mathrm{M}$ Tris- $\mathrm{HCl} \mathrm{pH}$ 8.0. Membrane receptor binding assays were performed as described previously (Gong et al. 1991). Briefly 1×10 CCL64 cells were incubated with 70,000 DPM ${ }^{125}$ I-labelled TGF- $\beta 1$ and different concentrations $(250 \mathrm{ng} / \mathrm{ml}-1 \mu \mathrm{g} / \mathrm{ml})$ of mouse $\mathrm{IgG}$ for 4 hours. After washing, cells were lysed overnight in $0.6 \mathrm{ml}$ of $20 \mathrm{mM} 4$-(2-hydroxyethyl)-1-piperazineethanesulfonic 
acid buffer, $\mathrm{pH} 7.5$, containing $1 \%$ Triton X-100, $10 \%$ glycerol and $0.01 \%$ BSA. Radioactivity and protein concentrations were determined with a gamma-counter and the BCA ${ }^{\mathrm{TM}}$ protein assay respectively. Receptor binding activity was represented as DPM per microgram protein (Gong et al. 1992).

Cell proliferation assay: The effects of TGF- $\beta 1$ and mouse IgG on CCL64 cell proliferation were determined by the WST-1 cell proliferation reagent as described previously (Shen et al. 2003b). Briefly $5 \times 10^{4}$ CCL64 cells were incubated with $0.5 \mathrm{ng} / \mathrm{ml}$ TGF- $\beta 1$ and different concentrations $(5 \mathrm{ng} / \mathrm{ml}$ and 10 $\mathrm{ng} / \mathrm{ml}$ ) of mouse IgG for 6 days. Culture medium containing TGF- $\beta 1$ and mouse IgG were changed every other day. At the end of the experiment, cells were incubated with $100 \mu$ of DMEM and $10 \mu \mathrm{l}$ of WST-1 cell proliferation reagent for 1 hour at $37^{0} \mathrm{C}$ with a plate-reader at $450 \mathrm{~nm}$ wavelength.

Animal model: Four groups of male Sprague-Dawley rats (6-8 rats/group), 4 weeks old and weighing 80-90 g, were employed. DMN-induced liver injury was selected on the basis of results from previous studies indicating that TGF- $\beta 1$ plays an important role in the development of the hepatic fibrosis associated with this model (Kuriyama et al. 2007). The first group underwent intraperitoneal (i.p.) injections of DMN (10mg/kg body weight) three times per week (three consecutive daily injections and 4 days off) for 4 weeks as described previously by Kondow et al (Kondou et al. 2003). A second group were treated in an identical manner but vaccinated with $\mathrm{HBVc}$ alone $(150 \mu \mathrm{g})$ in $0.1 \mathrm{ml}$ volume on two occasions subcutaneously. The first injection being on day 1 of DMN treatment and the second on day 14. The third group received $\mathrm{HBV}+\mathrm{C}(150 \mu \mathrm{g})$ as per group 2. The final group consisted of rats treated with PBS rather than DMN and remained unimmunized. After 4 weeks, all rats were sacrificed and serum obtained for alanine aminotransferase (ALT), hyaluronic acid (HA), TGF- $\beta 1$ and TGF- $\beta 1$ antibody analyses. In addition, livers were removed and separated into two parts: one part was fixed 
with 4\% paraformaldehyde in PBS for histological examination; the other frozen in liquid nitrogen and stored at $-80^{\circ} \mathrm{C}$ for subsequent RNA and protein extractions.

Biochemical analyses of serum: Serum ALT, HA, TGF- $\beta 1$ and antibodies to TGF- $\beta 1$ were documented by an ALT Kit from Catachem Inc. (Bridgeport, Connecticut, USA), Hyaluronic acid Quantitative Test Kit from Corgenix (Westminster, Colorado, USA), Quantikine Human TGF- $\beta 1$ Immunoassay kit from R\&D System (Minneapolis, USA) and an ELISA with 0.1ng recombinant TGF- $\beta 1$ as the coating protein respectively.

Histological and immunohistochemical staining: Paraffin embedded livers were cut in $4 \mu \mathrm{m}$ thin sections, mounted on glass slides and deparaffinized. Sections were then stained with hematoxylin-eosin (HE) or Masson's trichrome for histological analyses. For immunohistochemical staining, sections were incubated with proteinase $\mathrm{K}(20 \mu \mathrm{g} / \mathrm{ml})$ for $5 \mathrm{~min}$, blocked with peroxidase blocking reagent $(0.03 \%$ hydrogen peroxide and $0.2 \% \mathrm{NaN} 3$ ) for $30 \mathrm{~min}$ and then incubated with rabbit polyclonal antibodies against $\alpha$-smooth muscle actin (1:500 dilution) (AbCam, USA) or TGF- $\beta 1$ (1:200 dilution) (Santa Cruse, CA) at $4^{\circ} \mathrm{C}$ overnight. Goat anti-rabbit $\mathrm{IgG}$ conjugated with peroxidase-labeled polymer was then incubated with sections for $30 \mathrm{~min}$ at room temperature. Reaction products were visualized by incubating with 3.3-diaminobenzidine chromogen in imidazole buffer (containing hydrogen peroxide and $\mathrm{NaN} 3$ at $\mathrm{pH} 7.5)$.

Reverse-transcriptase polymerase chain reaction: Total RNA was isolated by Trizol reagent as per the manufacturer's instructions for liver tissue. The first strand cDNA synthesis and regular PCR were performed as described previously (Shen et al. 2003a). The specific primers for rat collagen type 1( $\alpha 1)$, $\alpha$-SMA and TGF- $\beta 1$ were designed by the Oligo 5.1 program on a Macintosh computer. The primers and PCR conditions are listed in Table 2. PCR amplification was carried out by applying 30 cycles comprising: denaturation at $94^{\circ} \mathrm{C}$ for 1 minute, annealing at different temperatures as in Table 2 for 30 
seconds, elongation at $72^{\circ} \mathrm{C}$ for 3 minutes, followed by a final elongation at $72^{\circ} \mathrm{C}$ for 8 min. using Eppendorf MasterCycler (Eppendorf, Westbury, NY). PCR products were analyzed by electrophoresis in a $1.5 \%$ agarose gel containing $0.1 \mathrm{mg} / \mathrm{ml}$ ethidium bromide and quantitated by the NIH Image program.

Statistics analysis: Statistical significance of differences was performed by employing the ANOVA and Fisher's PLSD tests with StatView software (version 5.0, SAS Institute Inc. Cary, NC). All measurements are expressed as mean \pm SD. Differences were considered to be significant when $p$ values were less than 0.05 .

\section{RESULTS}

The specificity of recombinant $\mathrm{HBVc}+\mathrm{C}$ vaccine was demonstrated in Figure 1. Mice immunized with purified HBVc+TGF- $\beta 1$ peptides generated antibodies against their respective antigens. However, only mice immunized with recombinant $\mathrm{HBVc}+\mathrm{C}$ protein induced antibody that was specific to recombinant human TGF- $\beta 1$ in appreciable titers (Figures $1 \mathrm{~A}$ and 1B). Moreover, purified serum IgG from mice immunized with recombinant $\mathrm{HBVc}+\mathrm{C}$ could block ${ }^{125}$ I-labelled TGF- $\beta 1$ binding to CCL64 cells in a dose-dependent manner (Figure 1C). Furthermore, only serum IgG from $\mathrm{HBVc}+\mathrm{C}$ immunized mice could interfere with the inhibitory effect of TGF- $\beta 1$ on CCL64 proliferation (Figure 1D).

The results of serum antibody to TGF- $\beta 1$ levels in saline and DMN treated rats with and without HBVc and recombinant $\mathrm{HBV}+\mathrm{C}$ vaccinations are provided in Figure 2. Significant antibody levels were only detected in rats treated with DMN and recombinant $\mathrm{HBV}+\mathrm{C}(\mathrm{p}<0.05)$. In this group anti-TGF- $\beta 1$ levels were more than twice those of HBVc vaccinated controls and triple those of DMN alone controls.

In terms of necroinflammatory activity and fibrogenesis, compared to healthy controls, serum ALT, TGF- $\beta 1$ and HA levels were elevated after 4 weeks in all DMN treated groups but in the case of ALT 
and HA levels the extent of the increase in $\mathrm{rHBVc}+\mathrm{C}$ immunized rats was significantly less than in DMN alone treated controls (Figure 3A).

Liver histology was also investigated in these groups (Figure 3B). There was significant necroinflammatory disease and fibrosis present in rats treated with DMN alone or DMN plus HBVc vaccination. However, in rats treated with $\mathrm{DMN}$ plus recombinant $\mathrm{HBV}+\mathrm{C}$ vaccination, both inflammation and fibrosis were attenuated (Figure 3B and 3C). Indeed, Masson staining in $\mathrm{HBVc}+\mathrm{C}$ immunized rat livers were more in keeping with healthy control rats that did not receive DMN.

Immunohistochemical staining for $\alpha$-SMA and TGF- $\beta 1$ in the liver revealed significant increases in $\alpha$ SMA and TGF- $\beta 1$ staining in DMN alone and DMN plus HBVc treated rats compared to rats treated with DMN plus recombinant $\mathrm{HBVc}+\mathrm{C}$ (Figure 4). However, once again, the extent of $\alpha-\mathrm{SMA}$ and TGF$\beta 1$ expression in $\mathrm{DMN}$ plus recombinant $\mathrm{HBVc}+\mathrm{C}$ treated rats was less than that of $\mathrm{DMN}$ alone treated rats and more in keeping with healthy control rat livers.

Figure 5 provides the results of RT-PCR analyses of liver tissues for collagen type I ( $\alpha 1), \alpha-S M A$ and TGF- $\beta 1$ mRNA. Rats treated with DMN alone, DMN plus HBVc and DMN plus recombinant $\mathrm{HBV}+\mathrm{C}$ all had significant increases in TGF- $\beta 1$ mRNA. However, only rats treated with DMN alone or DMN plus HBVc displayed increased abundance of collagen $I(\alpha 1)$ and $\alpha$-SMA mRNA while those immunized with recombinant $\mathrm{HBVc}+\mathrm{C}$ had significantly reduced expression.

No deaths occurred in any of the study groups.

\section{DISCUSSION}

Vaccine-based approaches are being considered more frequently for the treatment of various noninfectious disorders, particularly cancers. For example, peptides of xenogeneic vascular endothelial growth factor (VEGF) have been shown to induce the production of VEGF-specific auto-antibodies and 
thereby, inhibit cancer cell proliferation and tumor progression in animal models of cancer (Wei et al. 2000). In other studies, vaccination with chicken homologous matrix metalloproteinase-2, induced antibodies that exhibit marked anti-tumor properties ( $\mathrm{Su}$ et al. 2003). To our knowledge, this is unique attempt to employ a vaccine-based approach to the treatment of hepatic fibrosis.

TGF- $\beta 1$ plays a pivotal role in liver fibrosis and has been proposed as a surrogate marker. Serum TGF$\beta 1$ could be used to assess therapeutic outcome and short-term prognosis of HCV-related chronic hepatitis (Tarantino et al. 2008b). Suppressing the over-expression of TGF- $\beta 1$ or blocking its signaling pathway has been considered as a promising therapeutic strategy for liver fibrosis. For example, Two TGF-beta1 kinoid vaccines prepared by cross-linking TGF-beta1-derived polypeptides (TGF- $\beta 1(25)$ [41-65] and TGF- $\beta 1(30)-[83-112])$ to keyhole limpet hemocyanin (KLH) attenuated development of CCl4-induced liver fibrosis in BALB/c mice (Fan et al. 2013). Moreover, Vaccination against connective tissue growth factor (CTGF) that is downstream growth factor of TGF- $\beta 1$ inhibits fibrogenesis, alleviates hepatocyte apoptosis and facilitate hepatic regeneration (Li et al. 2016). The results of this study clearly indicate that vaccination with TGF- $\beta 1$ peptides incorporated within a recombinant $\mathrm{HBVc}$ induces the formation of TGF- $\beta 1$ antibodies that block TGF- $\beta 1$ binding to its receptor and inhibit hepatic stellate cell proliferation in vitro while attenuating hepatic fibrosis in an animal model of chronic liver disease.

We employed the hepatitis B virus core as our carrier protein because it has been demonstrated to form self-assembled particles when expressed in E. coli cells (Stahl et al. 1982). These stable particles can be easily purified and are highly immunogenic in laboratory animals (Cohen and Richmond 1982). Nonethe-less, although we constructed three recombinant constructs of $\mathrm{HBVc}$, only recombinant $\mathrm{HBVc}+\mathrm{C}$ formed self-assembled particles. Why the others did not is unclear, however, it has been reported that the length of insertion and certain amino acids (arginine rich C-terminals) can alter the ability to form 
self-assembled particles (Koletzki et al. 1997; Ulrich et al. 1992). In our study, the length of peptides should not have been an issue because all peptides were similar in length (between 9 and 12 amino acids). Thus, the composition of the amino acids may serve as a more likely explanation for this finding. It is important to note that although recombinant $\mathrm{HBVc}+\mathrm{C}$ vaccination resulted in a significant increase in antibody against TGF- $\beta 1$, serum TGF- $\beta 1$ protein and hepatic TGF- $\beta 1$ mRNA levels remained similar to those of the appropriate controls. Moreover, although hepatic TGF- $\beta 1$ mRNA levels remained unaltered, hepatic TGF- $\beta 1$ protein was reduced by vaccination with recombinant $\mathrm{HBV}+\mathrm{C}$. These observations raise the question as to whether vaccination with small TGF- $\beta 1$ peptide will contribute to a widespread disruption of cytokine homeostasis or whether the effect will be restricted to sites of tissue injury. Relevant to this issue is the belief that cytokine expression is largely regulated by local autocrine and paracrine activities. Indeed, previous studies have demonstrated that increases in TGF- $\beta 1$ and TGF$\beta 1$ receptor expression tend to be limited to sites of injury (Munger et al. 1999). In addition, only significant disruptions in tissue integrity allow large, circulating molecules such as $\operatorname{IgG}$, access to the cell surfaces of injured tissues. Accordingly, it is conceivable that the effects of antibodies derived from recombinant $\mathrm{HBV}+\mathrm{C}$ vaccination may be relatively restricted to the site of injury. None-the-less, additional studies are required to address this important issue.

A somewhat surprising finding in our study was the limited inflammatory cell infiltrate in the livers of DMN-treated rats vaccinated with recombinant $\mathrm{HBV} c+\mathrm{C}$ despite an elevation in serum ALT levels. While the explanation for this finding remains unclear, TGF- $\beta 1$ regulation of macrophage migration could explain why DMN-induced hepatocyte necrosis would remain unaffected while inflammatory cell migration is inhibited (Kim et al. 2006). Moreover, apoptotic cell death could be another reason because it is caspase-dependent and associated with mitochondrial membrane depolarization and cytochrome $c$ release (Tarantino et al. 2011). 
There are a number of limitations to this study that warrant emphasis. First, immunizations and DMN treatments were initiated simultaneously. Thus, it remains to be determined whether the vaccination strategy is of value in the setting of established fibrosis or cirrhosis. Second, the duration of vaccine efficacy needs to be determined in long-term studies. Third, although DMN-induced liver injury is a well-established model of chronic liver disease, studies employing other models in other animal species are still warranted. Fourth, with respect to future clinical applications, it must be noted that the immunogenicity of vaccines is suboptimal in the setting of advanced liver disease and in subjects receiving immunosuppressive regimens (Cheong et al. 2006; Kumar et al. 2011). Also to be determined is whether the recombinant $\mathrm{HBVc}+\mathrm{C}$ vaccine would be immunogenic in individuals with chronic $\mathrm{HBV}$ infections or antibodies to HBV core particles. Finally, no attempt was made to induce injury or inflammation outside the liver to determine whether "beneficial" wound healing would be impaired in TGF- $\beta 1$ vaccinated subjects, or to examine whether this recombinant vaccine are effective in attenuating development of liver fibrosis in non-alcoholic fatty liver disease, which has been shown enhanced serum concentration of TGF- $\beta 1$ (Tarantino et al. 2008a).

In conclusion, in this proof-of-concept study we have constructed a recombinant HBVc+TGF- $\beta 1$ peptide vaccine which generates antibodies against TGF- $\beta$ that inhibit TGF- $\beta 1$ binding and biological activities in vitro and the development of hepatic fibrosis in vivo. Further studies are required to determine whether this strategy has a role to play in the treatment of patients with chronic liver disease. 


\section{References}

Alcolado, R., Arthur, M.J., and Iredale, J.P. 1997. Pathogenesis of liver fibrosis. Clin. Sci. (Lond.) 92(2): 103-112.

Biernacka, A., Dobaczewski, M., and Frangogiannis, N.G. 2011. TGF-beta signaling in fibrosis. Growth Factors, 29(5): 196-202. doi: 10.3109/08977194.2011.595714.

Cheong, H.J., Song, J.Y., Park, J.W., Yeon, J.E., Byun, K.S., Lee, C.H., Cho, H.I., Kim, T.G., and Kim, W.J. 2006. Humoral and cellular immune responses to influenza vaccine in patients with advanced cirrhosis. Vaccine, 24(13): 2417-2422. doi: 10.1016/j.vaccine.2005.11.064.

Choi, H.S., Savard, C.E., Choi, J.W., Kuver, R., and Lee, S.P. 2007. Paclitaxel interrupts TGF-beta1 signaling between gallbladder epithelial cells and myofibroblasts. J. Surg. Res. 141(2): 183-191. doi: 10.1016/j.jss.2006.12.558.

Clouthier, D.E., Comerford, S.A., and Hammer, R.E. 1997. Hepatic fibrosis, glomerulosclerosis, and a lipodystrophy-like syndrome in PEPCK-TGF-beta1 transgenic mice. J. Clin. Invest. 100(11): 26972713. doi: 10.1172/JCI119815.

Cohen, B.J., and Richmond, J.E. 1982. Electron microscopy of hepatitis B core antigen synthesized in E. coli. Nature, 296(5858): 677-679.

Derynck, R. 1998. SMAD proteins and mammalian anatomy. Nature, 393(6687): 737-739. doi: $10.1038 / 31593$.

Dooley, S., Delvoux, B., Streckert, M., Bonzel, L., Stopa, M., ten Dijke, P., and Gressner, A.M. 2001. Transforming growth factor beta signal transduction in hepatic stellate cells via Smad2/3 phosphorylation, a pathway that is abrogated during in vitro progression to myofibroblasts. TGFbeta signal transduction during transdifferentiation of hepatic stellate cells. FEBS Lett. 502(1-2): 4-10. 
Fan, X., Zhang, Q., Li, S., Lv, Y., Su, H., Jiang, H., and Hao, Z. 2013. Attenuation of CCl4-induced hepatic fibrosis in mice by vaccinating against TGF-beta1. PLoS One, 8(12): e82190. doi: 10.1371/journal.pone.0082190.

George, J., Roulot, D., Koteliansky, V.E., and Bissell, D.M. 1999. In vivo inhibition of rat stellate cell activation by soluble transforming growth factor beta type II receptor: a potential new therapy for hepatic fibrosis. Proc. Natl. Acad. Sci. U. S. A. 96(22): 12719-12724.

Gong, Y., Anzai, Y., Murphy, L.C., Ballejo, G., Holinka, C.F., Gurpide, E., and Murphy, L.J. 1991. Transforming growth factor gene expression in human endometrial adenocarcinoma cells: regulation by progestins. Cancer Res. 51(20): 5476-5481.

Gong, Y., Ballejo, G., Murphy, L.C., and Murphy, L.J. 1992. Differential effects of estrogen and antiestrogen on transforming growth factor gene expression in endometrial adenocarcinoma cells. Cancer Res. 52(7): 1704-1709.

Karimian, G., Mohammadi-Karakani, A., Sotoudeh, M., Ghazi-Khansari, M., Ghobadi, G., and Shakiba, B. 2008. Attenuation of hepatic fibrosis through captopril and enalapril in the livers of bile duct ligated rats. Biomed. Pharmacother. 62(5): 312-316. doi: 10.1016/j.biopha.2007.10.020.

Kim, J.S., Kim, J.G., Moon, M.Y., Jeon, C.Y., Won, H.Y., Kim, H.J., Jeon, Y.J., Seo, J.Y., Kim, J.I., Kim, J., Lee, J.Y., Kim, P.H., and Park, J.B. 2006. Transforming growth factor-beta1 regulates macrophage migration via RhoA. Blood, 108(6): 1821-1829. doi: 10.1182/blood-2005-10-009191.

Koletzki, D., Zankl, A., Gelderblom, H.R., Meisel, H., Dislers, A., Borisova, G., Pumpens, P., Kruger, D.H., and Ulrich, R. 1997. Mosaic hepatitis B virus core particles allow insertion of extended foreign protein segments. J. Gen. Virol. 78 ( Pt 8): 2049-2053. 
Kondou, H., Mushiake, S., Etani, Y., Miyoshi, Y., Michigami, T., and Ozono, K. 2003. A blocking peptide for transforming growth factor-beta1 activation prevents hepatic fibrosis in vivo. J. Hepatol. 39(5): 742-748.

Kramer, I.M., Koornneef, I., de Laat, S.W., and van den Eijnden-van Raaij, A.J. 1991. TGF-beta 1 induces phosphorylation of the cyclic AMP responsive element binding protein in ML-CCl64 cells. EMBO J. 10(5): 1083-1089.

Kumar, D., Blumberg, E.A., Danziger-Isakov, L., Kotton, C.N., Halasa, N.B., Ison, M.G., Avery, R.K., Green, M., Allen, U.D., Edwards, K.M., Miller, G., and Michaels, M.G. 2011. Influenza vaccination in the organ transplant recipient: review and summary recommendations. Am. J. Transplant. 11(10): 20202030. doi: 10.1111/j.1600-6143.2011.03753.x.

Kuriyama, S., Yokoyama, F., Inoue, H., Takano, J., Ogawa, M., Kita, Y., Yoshiji, H., Deguchi, A., Kimura, Y., Himoto, T., Yoneyama, H., Kurokohchi, K., Masaki, T., Uchida, N., and Watanabe, S. 2007. Sequential assessment of the intrahepatic expression of epidermal growth factor and transforming growth factor-beta1 in hepatofibrogenesis of a rat cirrhosis model. Int. J. Mol. Med. 19(2): 317-324.

Li, S., Lv, Y.F., Su, H.Q., Zhang, Q.N., Wang, L.R., and Hao, Z.M. 2016. A virus-like particle-based connective tissue growth factor vaccine suppresses carbon tetrachloride-induced hepatic fibrosis in mice. Sci. Rep. 6: 32155. doi: 10.1038/srep32155.

Ma, Y., HayGlass, K.T., Becker, A.B., Fan, Y., Yang, X., Basu, S., Srinivasan, G., Simons, F.E., Halayko, A.J., and Peng, Z. 2007. Novel recombinant interleukin-13 peptide-based vaccine reduces airway allergic inflammatory responses in mice. Am. J. Respir. Crit. Care Med. 176(5): 439-445. doi: 10.1164/rccm.200610-1405OC.

Munger, J.S., Huang, X., Kawakatsu, H., Griffiths, M.J., Dalton, S.L., Wu, J., Pittet, J.F., Kaminski, N., Garat, C., Matthay, M.A., Rifkin, D.B., and Sheppard, D. 1999. The integrin alpha v beta 6 binds and 
activates latent TGF beta 1: a mechanism for regulating pulmonary inflammation and fibrosis. Cell, 96(3): 319-328.

Qi, Z., Atsuchi, N., Ooshima, A., Takeshita, A., and Ueno, H. 1999. Blockade of type beta transforming growth factor signaling prevents liver fibrosis and dysfunction in the rat. Proc. Natl. Acad. Sci. U. S. A. 96(5): 2345-2349.

Sanderson, N., Factor, V., Nagy, P., Kopp, J., Kondaiah, P., Wakefield, L., Roberts, A.B., Sporn, M.B., and Thorgeirsson, S.S. 1995. Hepatic expression of mature transforming growth factor beta 1 in transgenic mice results in multiple tissue lesions. Proc. Natl. Acad. Sci. U. S. A. 92(7): 2572-2576.

Shen, H., Huang, G., Hadi, M., Choy, P., Zhang, M., Minuk, G.Y., Chen, Y., and Gong, Y. $2003 a$. Transforming growth factor-beta1 downregulation of Smad1 gene expression in rat hepatic stellate cells. Am. J. Physiol. Gastrointest. Liver Physiol. 285(3): G539-546. doi: 10.1152/ajpgi.00436.2002.

Shen, H., Huang, G.J., and Gong, Y.W. 2003b. Effect of transforming growth factor beta and bone morphogenetic proteins on rat hepatic stellate cell proliferation and trans-differentiation. World J. Gastroenterol. 9(4): 784-787.

Stahl, S., MacKay, P., Magazin, M., Bruce, S.A., and Murray, K. 1982. Hepatitis B virus core antigen: synthesis in Escherichia coli and application in diagnosis. Proc. Natl. Acad. Sci. U. S. A. 79(5): 16061610.

Strack, I., Schulte, S., Varnholt, H., Schievenbusch, S., Tox, U., Wendland, K., Steffen, H.M., Drebber, U., Dienes, H.P., and Odenthal, M. 2011. beta-Adrenoceptor blockade in sclerosing cholangitis of Mdr2 knockout mice: antifibrotic effects in a model of nonsinusoidal fibrosis. Lab. Invest. 91(2): 252-261. doi: 10.1038/labinvest.2010.162.

Su, J.M., Wei, Y.Q., Tian, L., Zhao, X., Yang, L., He, Q.M., Wang, Y., Lu, Y., Wu, Y., Liu, F., Liu, J.Y., Yang, J.L., Lou, Y.Y., Hu, B., Niu, T., Wen, Y.J., Xiao, F., Deng, H.X., Li, J., and Kan, B. 2003. 
Active immunogene therapy of cancer with vaccine on the basis of chicken homologous matrix metalloproteinase-2. Cancer Res. 63(3): 600-607.

Tarantino, G., Colao, A., Capone, D., Conca, P., Tarantino, M., Grimaldi, E., Chianese, D., Finelli, C., Contaldo, F., Scopacasa, F., and Savastano, S. 2011. Circulating levels of cytochrome C, gammaglutamyl transferase, triglycerides and unconjugated bilirubin in overweight/obese patients with nonalcoholic fatty liver disease. J. Biol. Regul. Homeost. Agents, 25(1): 47-56.

Tarantino, G., Conca, P., Riccio, A., Tarantino, M., Di Minno, M.N., Chianese, D., Pasanisi, F., Contaldo, F., Scopacasa, F., and Capone, D. 2008a. Enhanced serum concentrations of transforming growth factor-beta1 in simple fatty liver: is it really benign? J. Transl. Med. 6: 72. doi: 10.1186/14795876-6-72.

Tarantino, G., Coppola, A., Conca, P., Cimino, E., and Di Minno, G. 2008b. Can serum TGF-beta 1 be used to evaluate the response to antiviral therapy of haemophilic patients with HCV-related chronic hepatitis? Int. J. Immunopathol. Pharmacol. 21(4): 1007-1012.

Tox, U., and Steffen, H.M. 2006. Impact of inhibitors of the Renin-Angiotensin-aldosterone system on liver fibrosis and portal hypertension. Curr. Med. Chem. 13(30): 3649-3661.

Ulrich, R., Borisova, G.P., Gren, E., Berzin, I., Pumpen, P., Eckert, R., Ose, V., Siakkou, H., Gren, E.J., von Baehr, R., and et al. 1992. Immunogenicity of recombinant core particles of hepatitis B virus containing epitopes of human immunodeficiency virus 1 core antigen. Arch. Virol. 126(1-4): 321-328.

Wei, Y.H., Jun, L., and Qiang, C.J. 2004. Effect of losartan, an angiotensin II antagonist, on hepatic fibrosis induced by CCl4 in rats. Dig. Dis. Sci. 49(10): 1589-1594.

Wei, Y.Q., Wang, Q.R., Zhao, X., Yang, L., Tian, L., Lu, Y., Kang, B., Lu, C.J., Huang, M.J., Lou, Y.Y., Xiao, F., He, Q.M., Shu, J.M., Xie, X.J., Mao, Y.Q., Lei, S., Luo, F., Zhou, L.Q., Liu, C.E., Zhou, 
H., Jiang, Y., Peng, F., Yuan, L.P., Li, Q., Wu, Y., and Liu, J.Y. 2000. Immunotherapy of tumors with xenogeneic endothelial cells as a vaccine. Nat. Med. 6(10): 1160-1166. doi: 10.1038/80506.

Yata, Y., Gotwals, P., Koteliansky, V., and Rockey, D.C. 2002. Dose-dependent inhibition of hepatic fibrosis in mice by a TGF-beta soluble receptor: implications for antifibrotic therapy. Hepatology, 35(5): 1022-1030. doi: 10.1053/jhep.2002.32673. 


\section{Figure Legends}

Figure 1: Specificity of serum and/or antibody generated by immunization of mice with $\mathrm{HBVc+C}$ vaccine: Panel A reveals the specificity of different sera against TGF- $\beta 1$. Panel B displays binding of serum from mice immunized with $\mathrm{HBVc}$ or $\mathrm{HBVc}+\mathrm{C}$ vaccines to TGF- $\beta 1 \mathrm{C}$ peptide. Panel $\mathrm{C}$ shows blocking of ${ }^{125}$ I-labelled TGF- $\beta 1$ binding to CCL64 cell membrane receptors by various concentrations of purified IgG from mice immunized with $\mathrm{HBVc}+\mathrm{C}$. Panel D represents blocking TGF- $\beta 1$ inhibition of CCL64 cell proliferation. Data are presented as mean \pm SD from 6 wells on 3 occasions.

Figure 2: Immunization of recombinant $\mathrm{HBVc}+\mathrm{C}$ in the $\mathrm{DMN}$ model of chronic liver disease induces antibody against TGF- $\beta 1$. Rats were separated into four groups: healthy controls, DMN alone, DMN plus vaccination with HBVc $(150 \mu \mathrm{g} / \mathrm{kg}$ body weight), and DMN plus vaccination with $\mathrm{rHBVc}+\mathrm{C}(150$ $\mu \mathrm{g} / \mathrm{kg}$ body weight). Rat serum was obtained and immunoreaction to TGF- $\beta 1$ was examined. As shown in the Figure, there was significant immunoreaction against TGF- $\beta 1$ in the sera of rats treated with $\mathrm{DMN}$ plus rHBVc+C protein. There was also immunoreaction against TGF- $\beta 1$ in the sera of rats treated with DMN alone and DMN plus HBVc protein but to a lesser and not statistically significant extent. Data represent the mean $\pm \mathrm{SD}$ from 6 rats. * indicates $p<0.05$.

Figure 3: Serum levels of ALT, TGF- $\beta 1$ and hyaluronic acid (HA) and histological analyses. Panel $A$ provides the results of serum ALT, TGF- $\beta 1$ and HA levels. Panel $B$ represents liver sections from four groups of rats - healthy controls (subpanel $a$ ), treatment with DMN alone (subpanel $b$ ), DMN plus immunization with HBVc (150 $\mu \mathrm{g} / \mathrm{kg}$ body weight) (subpanel c), DMN plus immunization with $\mathrm{rHBVc}+\mathrm{C}(150 \mu \mathrm{g} / \mathrm{kg}$ body weight) (subpanel $d)$. Quantitatively, there was less collagen in the livers of 
rats treated with $\mathrm{DMN}+\mathrm{rHBV}+\mathrm{C}($ Panel $C)$. Data represent mean $\pm \mathrm{SD}$ from 6 rats. * indicates $p<0.05$.

Figure 4: Immunohistochemical analyses of $\alpha$-SMA and TGF- $\beta 1$ expression. Panels $A$ and $B$ represent the results for $\alpha$-SMA and TGF- $\beta 1$ respectively. Subpanels $a, b, c$, and $d$ indicate liver sections from the four groups of rats as indicated in Figure 2. Slide intensity was quantitated and shown in the bottom section of each panel. Compared to DMN alone treated controls, $\alpha-S M A$ and TGF- $\beta 1$ staining in the livers of rats treated with $\mathrm{DMN}+\mathrm{HBVc}+\mathrm{C}$ were significantly reduced. Data represent mean $\pm \mathrm{SD}$ from 6 rats. * indicates $p<0.05$.

Figure 5: Expression of TGF- $\beta 1$, collagen $\alpha 1(\mathrm{I})$ and $\alpha$-SMA mRNA in the livers of the four groups of rats. mRNAs were extracted from the livers by the Trizol reagent and TGF- $\beta 1$, collagen I ( $\alpha 1), \alpha$-SMA and GAPDH mRNA expression examined by RT-PCR. The left panel shows typical PCR gels while the right panel indicates the relative expression of TGF- $\beta 1$, collagen I ( $\alpha 1)$ and $\alpha$-SMA, corrected for GAPDH. Although TGF- $\beta 1$ mRNA remained unaltered, there were significant reductions of collagen I ( $\alpha 1)$ and $\alpha$-SMA mRNAs in the livers of rats immunized with $\mathrm{rHBVc}+\mathrm{C}$ compared to rats treated with DMN alone. Data represent mean \pm SD from 6 rats. * represents $p<0.05$. 
Table 1: Sequences of TGF- $\beta 1$ peptides

\begin{tabular}{|l|l|l|}
\hline Peptides & Sequence & Position \\
\hline A & $\begin{array}{l}\text { Sense: 5'-TCTACCGAGAAGAACTGCTGCGTGAGACAGCTGTATATT-3' } \\
\text { Antisense: 5'-AATATACAGCTGTCTCAGGCAGCAGTTCTTCTCGGTAGA-3' }\end{array}$ & 28-66 \\
\hline B & $\begin{array}{l}\text { Sense: 5'-TATTCTAAAGTGCTGGCGCTGTATAAT-3' } \\
\text { Antisense: 5'-ATTATACAGCGCCAGCACTTTAGAATA-3' }\end{array}$ & $171-198$ \\
\hline C & $\begin{array}{l}\text { Sense: 5'-CAGCATAATCAGGGTGCATCTGCAGCT-3' } \\
\text { Antisense: 5'-AGCTGCAGATGCACCCGGATTATGCTG-3' }\end{array}$ & $198-225$ \\
\hline
\end{tabular}


Table 2: Primers and PCR conditions of rat genes

\begin{tabular}{|l|l|l|l|}
\hline Name & Primer sequences & Tm $\left({ }^{0} \mathrm{C}\right)$ & Length (bp) \\
\hline Collagen Type & Sense: 5'-TCCCTACCCAGCAGGTTCAAATCC-3' & 58 & 269 \\
\hline$\alpha$-SMA & Antisense: 5'-TCCCACCCCACCCCTTCAC-3' & Sense: 5'-CACGGCATCATCACCAAC-3' & \\
& Antisense: 5'-GGAAGAAGAGGAAGCAGCAG-3' & 58 & 389 \\
\hline TGF- $\beta 1$ & Sense: 5'-GGCCTGGACCTTGCAGGAGCGCAC-3' & 58 & 289 \\
& Antisense: 5'GCTGCACTTGCAGGAGCGCAC-3' & & \\
\hline GAPDH & Sense: 5'-GATGCTGGTGCTGAGTATGTCGT & 64 & 869 \\
& Antisense: 5'-GGGATGGAATTGTGAGGGAGATG-3' & & \\
\hline
\end{tabular}




\section{Page 23 of 27}
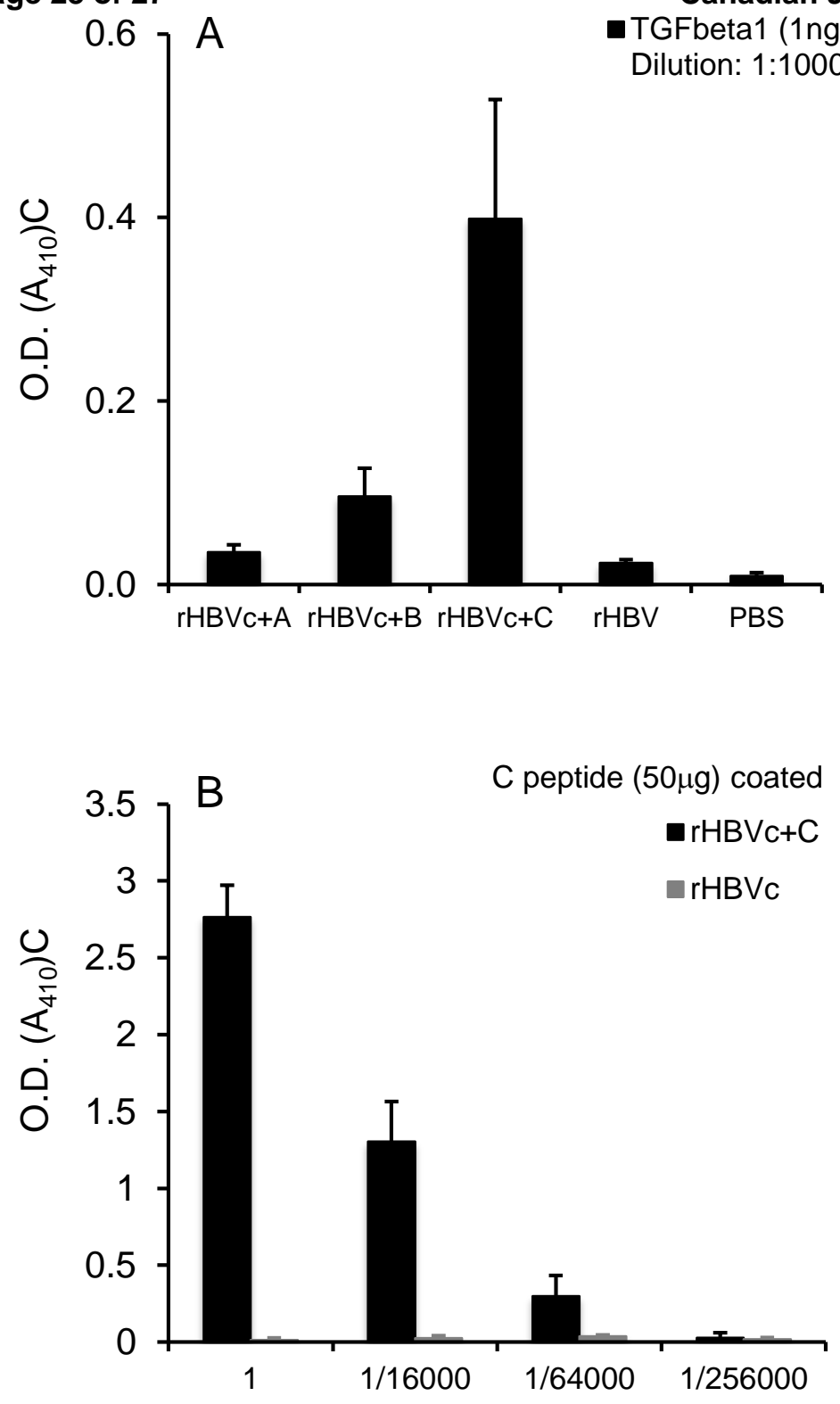

Serum dilution
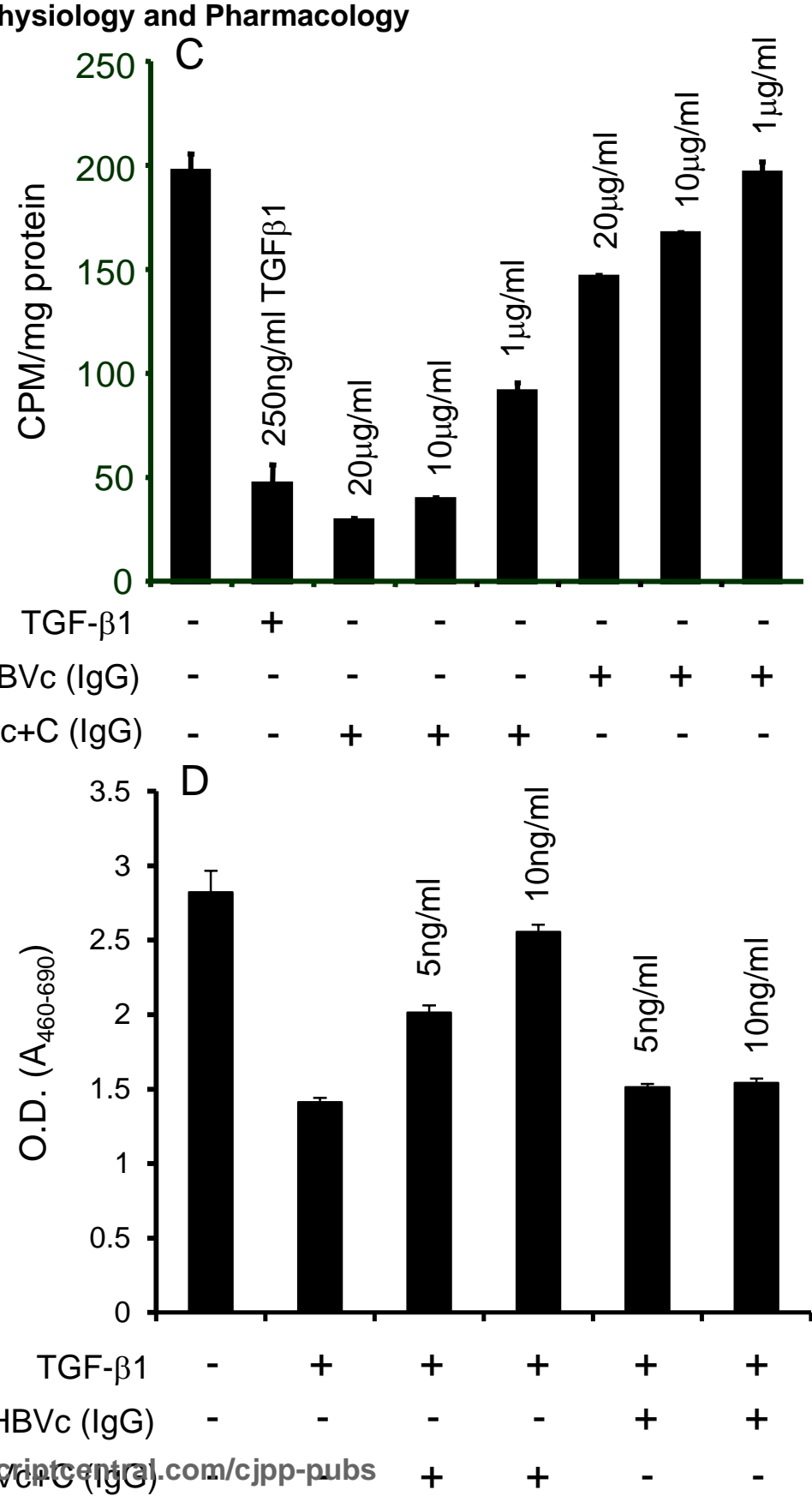

Figure 1

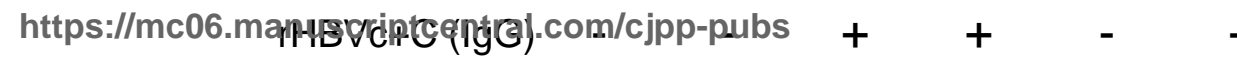




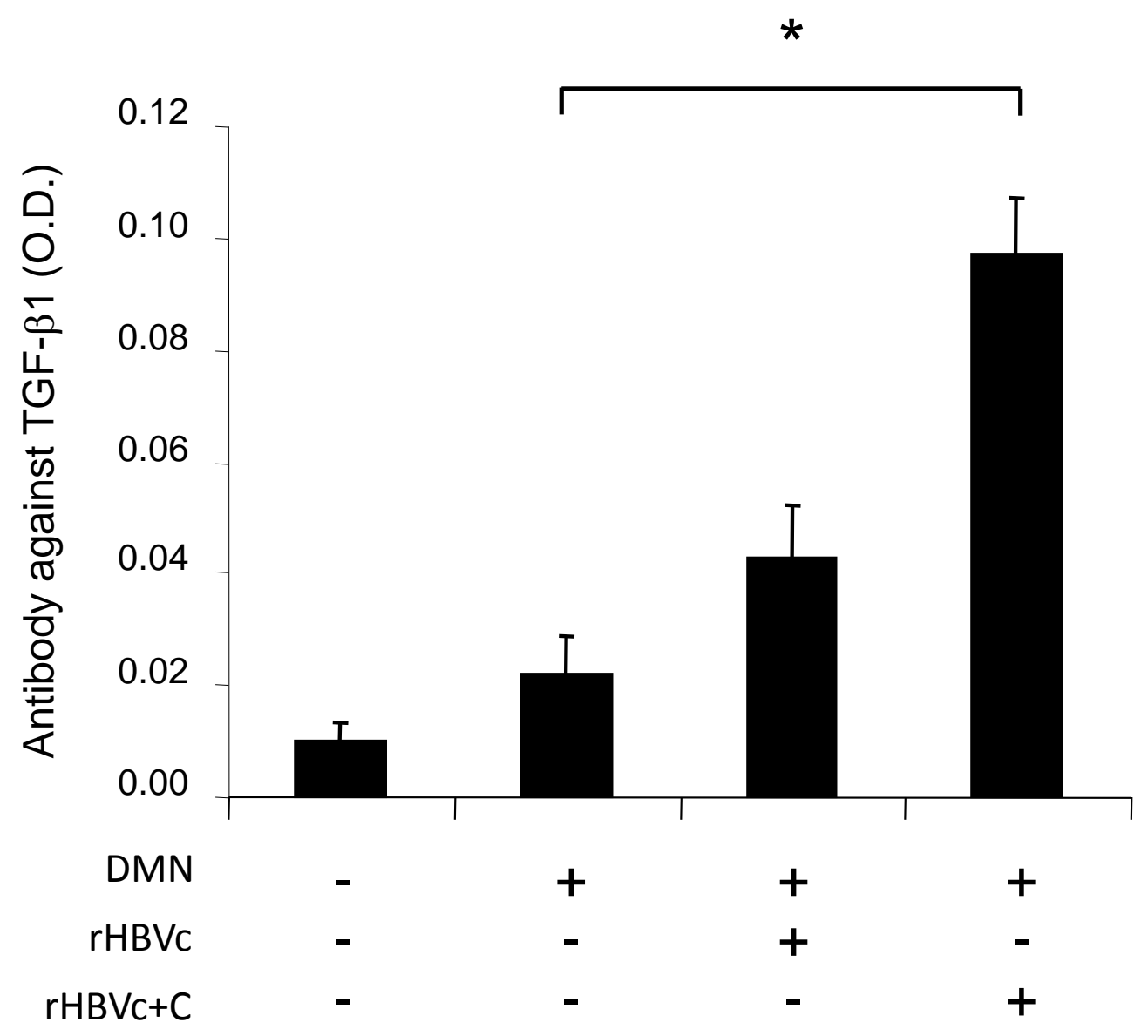

https://mc06.manuscriptcentral.com/cjpp-pubs

Figure 2 


\section{Page 25 of 27}
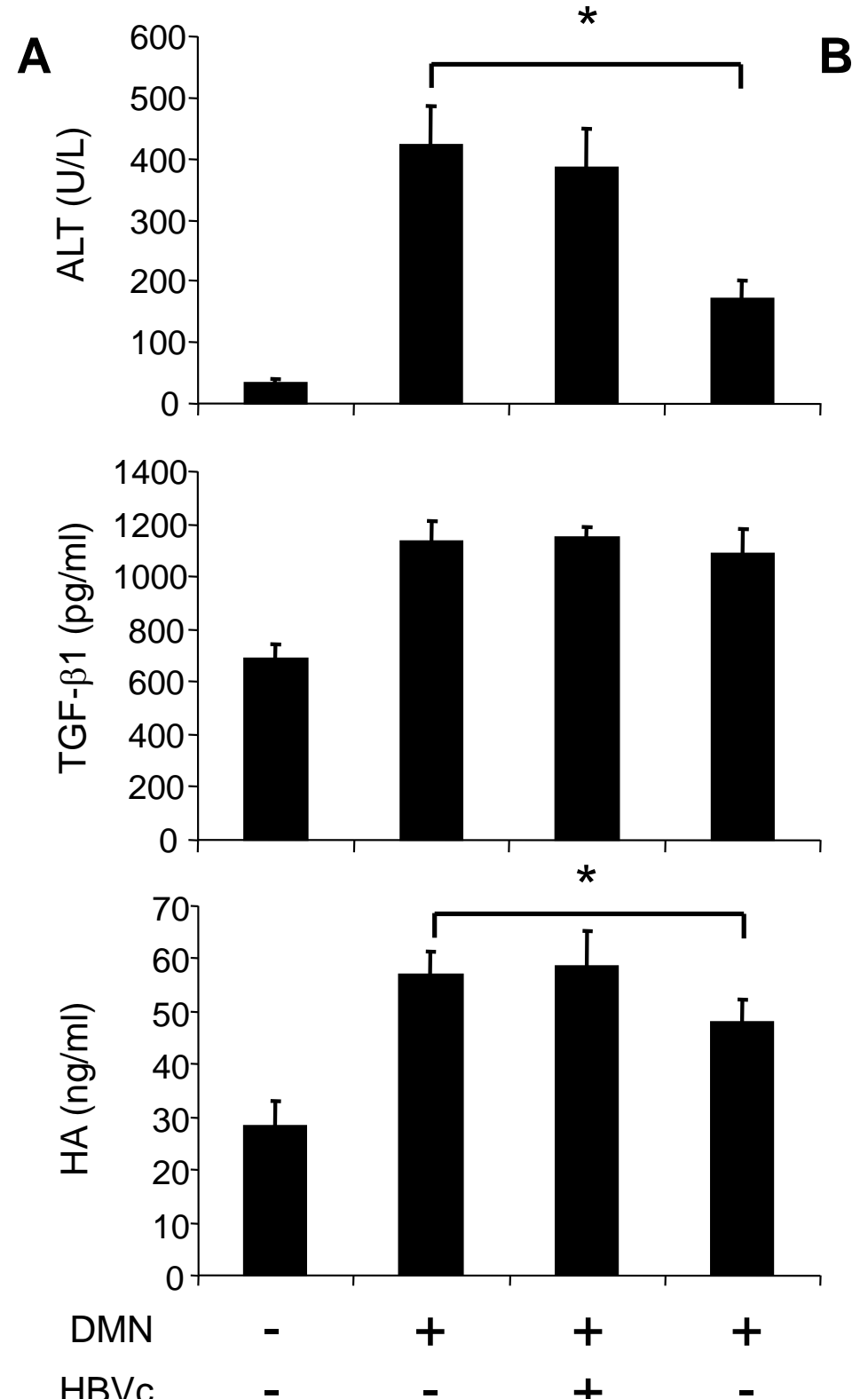

B

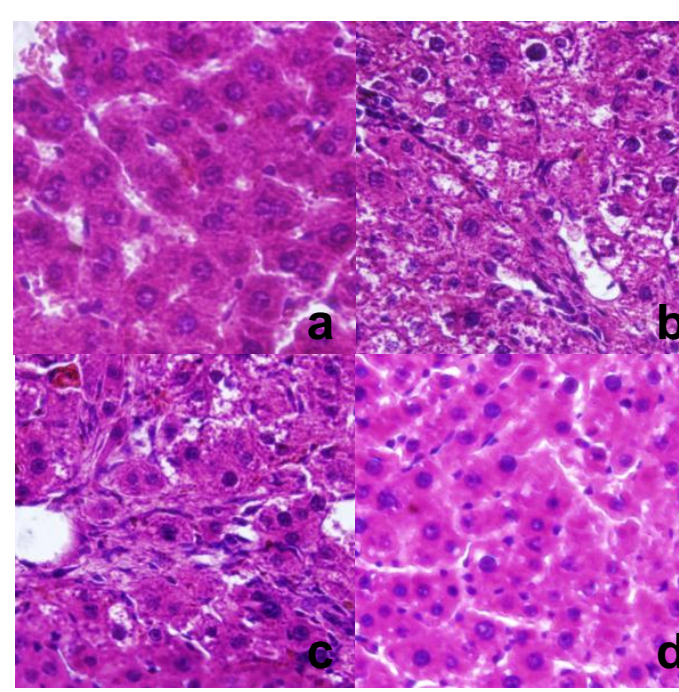

HE Staining
Masson Staining

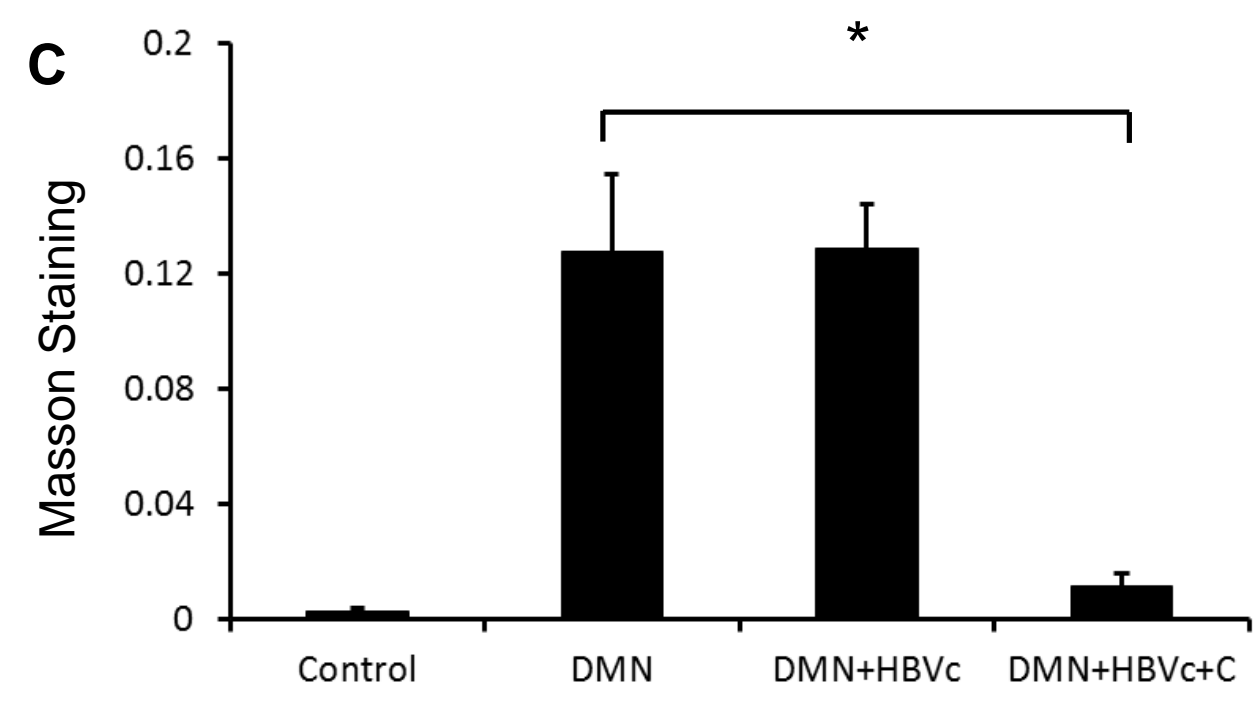

$\mathrm{rHBV}+\mathrm{C}$

$-$ 

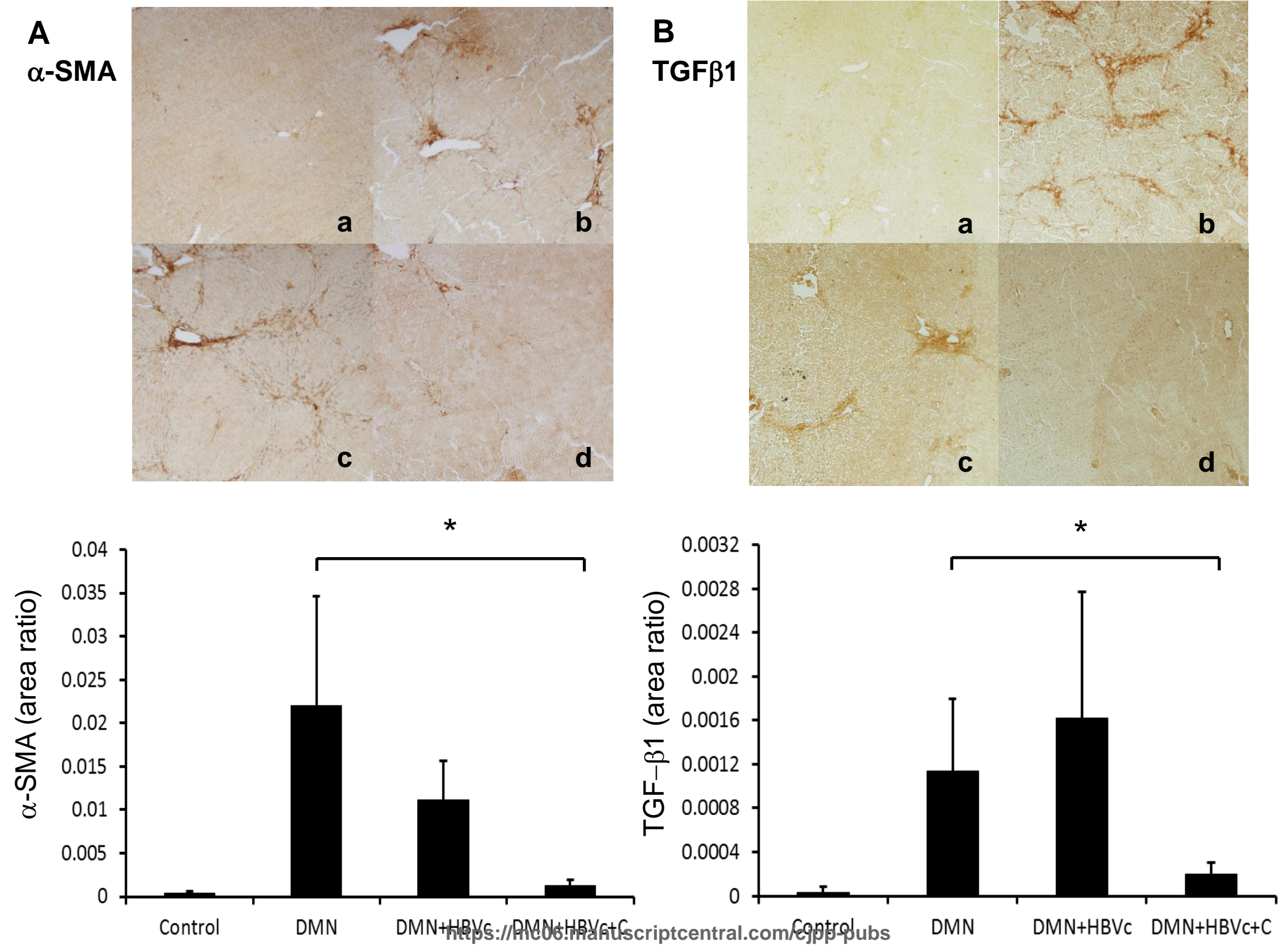

Figure 4 


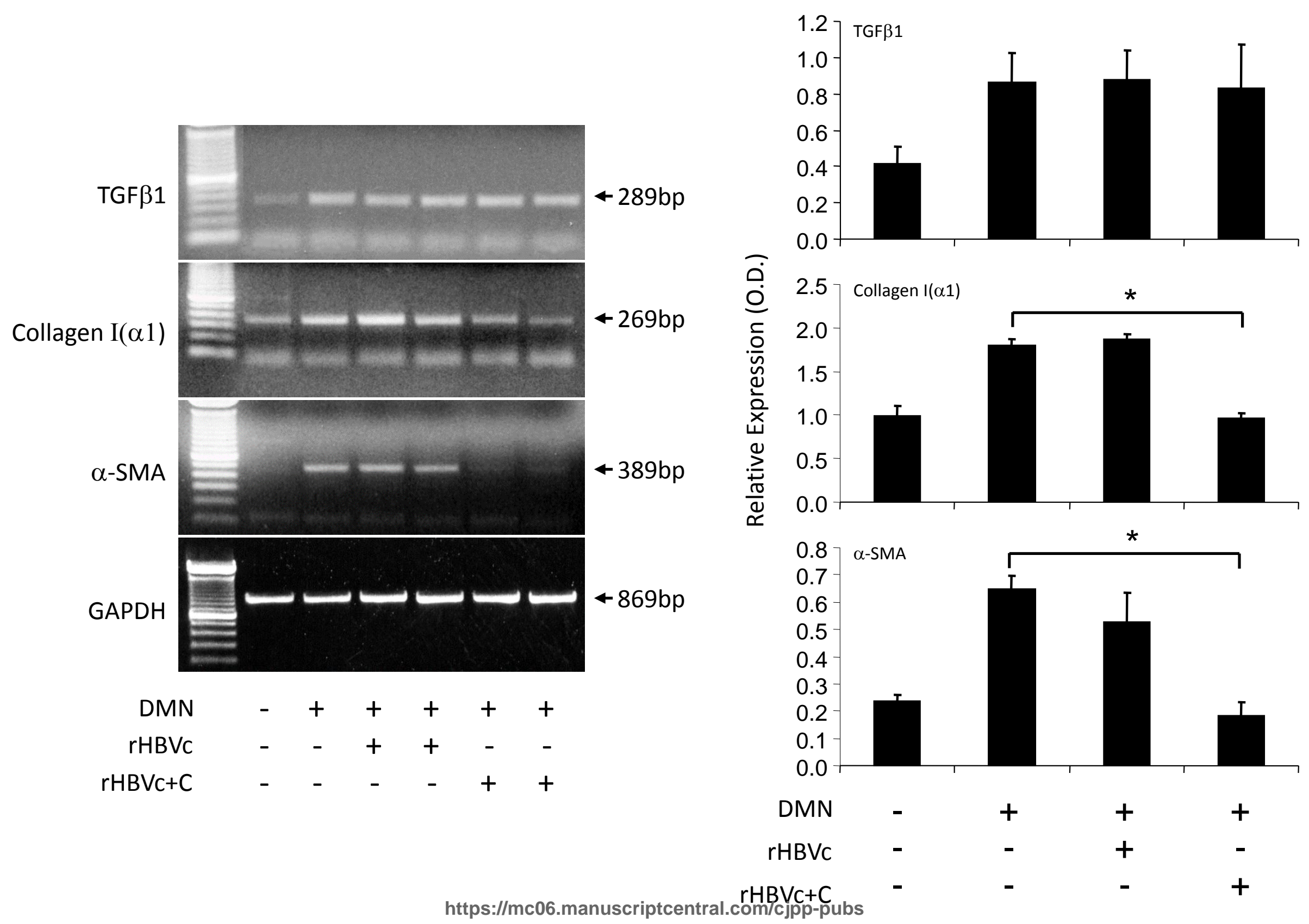

Figure 5 